\title{
Kop Bölgesi Üniversiteleri Turizm Fakültesi Öğrencilerinin Boş Zaman Faaliyetlerine Bakış Açılarının İncelenmesi ${ }^{I}$
}

\author{
Investigation of Students' Views on Leisure Activities of the Schools of Tourism of \\ Kop Region Universities \\ Sinan BÖLÜKBAŞ* \\ Serdar BÜYÜKIPEKCI $I^{* *}$
}

\begin{abstract}
$\ddot{O} Z$
Bu araştırmayla ÜNIKOP kapsamındaki üniversitelerin turizm fakültelerinde öğrenim görmekte olan öğrencilerin boş zaman etkinliklerine karşı tutumlarının belirlenmesi, boş zamanlarını nasıl değerlendirdikleri ve boş zaman etkinliklerine ne sıklkkla katıldlkları, boş zaman tutumlarında cinsiyet, sosyo-ekonomik durum, ailenin eğitim durumu, kalınan yer ve aile yaşam yerinin etkisinin olup olmadı̆̆ının tespiti amaçlandı. Çalışmada, öğrencilerin boş zaman tutum düzeylerini ölçebilmek için "Boş Zaman Tutum Ölçeği", anket formu kullanılmıştır. Öğrencilerin demografik özellikleri hakkında bilgi toplamak amacıyla da "Kişisel Bilgi Formu" kullanılmıștır. Veri analizinde \%, ortalama, standart sapma analizlerinden yararlanılmıştır. Boş zaman tutumu farklılı̆̆ını ortaya koymak amacı ile t testi ve ANOVA kullanılmuştır. Yapılan analizler sonucunda anlamlı farklılı̆̆ın ortaya çıkması durumunda, farklılığın hangi gruplar arasında olduğunu belirlemek için varyansların homojenliği kontrol edilmiş olup, varyansların homojen olması durumunda çoklu karşılaştırma testlerinden tukey testi, kullanılmıştır. Verilerin istatistiksel analizinde ve yorumlarda, $p<0,05$ anlamlllık düzeyi dikkate alınmıştır. Kop bölgesi üniversiteleri turizm fakültesi öğrencilerin boş zaman tutumlarında demografik özelliklerden gelir, aile yaşam yeri ve baba eğitimine göre bir değişiklik olmazken anne eğitiminin bilişsel ve duyuşsal alanda anlamlı farklllık oluşturduğu bulunmuştur. Yine cinsiyetin öğrencilerin boş zaman tutumunu etkilediği kız ögrrencilerin erkek öğrencilere göre daha olumlu bir tutuma sahip oldukları görülmüştür. Sonuç olarak KOP bölgesi üniversiteleri turizm fakültesi son sinıf ögrencileri rekreasyon faaliyetlerine katıllmın başarılarını artırdığını, rekreasyonel etkinliklere katılım için yeterli boş zamana sahip olduklarını fakat bu boş zamanların yeterli düzeyde olumlu kullanamadıklarını, üniversitenin sunduğu boş zaman olanaklarını yetersiz bulduklarını ifade etmişlerdir.
\end{abstract}

\section{ANAHTAR KELIMELER}

Boş zaman, Rekreasyon, KOP Bölgesi, Üniversite öğrencileri

\begin{abstract}
With this research, it is aimed to determine the attitudes of students studying in tourism faculties of universities within the scope of ÜNIKOP towards leisure activities, how they evaluate their leisure time and how often they participate in leisure activities, the aim of the study was to determine whether gender, socio-economic status, education level of the family, place of residence and family place of residence had an effect on leisure attitudes. In the study, "Leisure Attitude Scale" questionnaire form was used to measure the leisure attitude levels of students. The "Personal Information Form" was used to collect information about the demographic characteristics of the students. Average, \%, and standard deviation analyzes were used for data analyze. T test and ANOVA were used to reveal the difference of leisure attitude. In case of significant difference occur as a result of the analysis, the homogeneity of the variances was checked to determine which groups were different. And if the variances were homogeneous, tukey test was used. In the statistical analysis and interpretation of the data, $p<0.05$ significance level was taken into consideration. There was no change in the leisure time attitudes of the students of the tourism faculties of Kop region universities according to income, family place of residence and father education among demographic features. It was found that maternal education made a significant difference in cognitive and affective domains. It was seen that female students had a more positive attitude than male students, where gender affected students' leisure time attitude. As a result, final year students from the tourism faculty of KOP universities stated that participation in recreation activities increased their success, and they stated that they had enough leisure time to participate in recreational activities but they could not use these leisure time positively and found that the leisure facilities offered by the university were inadequate.
\end{abstract}

KEYWORDS

Leisure time, Recreation, KOP Area, University students

\begin{tabular}{|c|c|c|}
\hline & $\begin{array}{c}\text { Makale Geliş Tarihi / Submission Date } \\
\text { 20.02.2020 }\end{array}$ & $\begin{array}{c}\text { Makale Kabul Tarihi / Date of Acceptance } \\
31.03 .2020\end{array}$ \\
\hline Attf & \multicolumn{2}{|c|}{$\begin{array}{l}\text { Bölükbaş, S. ve Büyükipekci, S. (2020). Kop Bölgesi Üniversiteleri Turizm Fakültesi Öğrencilerinin Boş Zaman } \\
\text { Faaliyetlerine Bakış Açılarının İncelenmesi. Selçuk Universitesi Sosyal Bilimler Meslek Yüksekokulu Dergisi, } 23 \text { (1), } \\
\text { 341-357. }\end{array}$} \\
\hline
\end{tabular}

${ }^{1}$ Bu çalışma Sosyal Bilimler Enstitüsü, Rekreasyon Yönetimi, Yüksek Lisans Öğrencisi Sinan BÖLÜKBAŞ’ın “Kop Bölgesi Üniversiteleri Turizm Fakültesi Öğrencilerinin Boş Zaman Faaliyetlerine Bakış Açılarının İncelenmesi” isimli tezinden türetilmiştir.

* Necmettin Erbakan Üniversitesi, Sosyal Bilimler Enstitüsü, Rekreasyon Yönetimi, Yüksek Lisans Öğrencisi, guzelbey68@hotmail.com, ORCID 0000-0001-5410-302X

** Dr.Öğr.Üyesi, Necmettin Erbakan Üniversitesi, Meram Meslek Yüksekokulu, sbuyukipekci@erbakan.edu.tr, ORCID: 0000-0001-8724-5374 


\section{GİRIŞ}

KOP Bölgesi Üniversiteler Birliği (ÜNIKOP) KOP bölgesi üniversiteleri arasında eğitim-öğretim, araştırma-geliştirme ve toplumsal hizmet gibi alanlarda akademik ve idari işbirlikleri yapmak, üniversitesanayi etkileşimi ve üniversite-şehir bütünleşmesini ileri düzeye taşımak, ülkemizin gelecek vizyonuna ve kalkınma çabalarına katkı sağlamak amacıyla kurulmuştur. ÜNIKOP 11 devlet ve 2 vakıf üniversitesi olan on üç üniversiteden oluşmaktadır. On üç üniversitenin dört tanesinde turizm fakültesi bulunmaktadır.

Turizm fakültesi öğrencilerinin gelecekte işlerinin bir parçası olacak olan boş zaman etkinliklerine karşı tutumları, rekreasyon ve boş zaman farkındalıkları, üniversite yıllarında boş zaman etkinliklerine katılım düzeyleri, turizm fakültelerinin yeterli düzeyde rekreatif etkinlik firsatları sunup sunmadığının tespiti yapılarak turizm ve rekreasyon konusunda gelecekte yapılacak çalışmalara 1şık tutulacaktır.

Günümüzde bireylerin yaşamında boş zamanın verimli bir şekilde değerlendirilmesi kişilerin sağlıklı gelişimi, mutluluğu ve toplumsal bütünleşme için gereklilik haline gelmiştir. İnsanın yaşamında önemli bir boşluğu dolduran boş zamanın bilinçli şekilde değerlendirilmesinde rekreasyon önemli bir işlev görmektedir.

\section{BOŞ ZAMAN}

Literatüre bakıldığında boş zaman kavramını genel olarak tanımlamak gerekirse iş, uyku, ulaşım, yemeiçme, kişisel bakım gibi temel gereksinimleri karşıladıktan sonra bireyin özgür olduğu kendi istediği etkinlikler ile uğraşabileceği zamandır. Tanımlamalardan anlaşıldığ kendi seçeceği ve yapmaktan zevk aldığı etkinliklerle uğraşacağı zaman olduğu belirtilmektedir.

Boş zaman bireyin çalışma zamanı dışında kalan, yaşamsal ihtiyaçlarını ve sorumluluklarını yerine getirdikten sonra artakalan, bireyin isteği doğrultusunda kullanabileceği zaman olarak ifade edilmektedir (Karaküçük,2005:37).

Boş zaman bireyin çalışma zamanı dışında kalan, zorunlu ihtiyaçlarının ve görevlerini yerine getirdikten sonra artakalan ve tercihi doğrultusunda kullanabileceği zamandır (Kılbaş, 2010:4). Boş zaman, yaşamın zorunlu ihtiyaçlarını yerine getirdikten sonra bireye artakalan, bireyin istediği gibi kullanabileceği zaman dilimidir (Torkildsen, 2005:50).

\section{REKREASYON}

Rekreasyon insanların iş hayatı dışında kalan sosyal, zihinsel ve ruhsal güdülenmeler temelinde dinlenme, eğlenme, yenilenme ve kişisel gelişimlerine katkı sağlamak amacıyla özgür iradeleriyle gönüllü olarak katıldıkları boş zaman aktiviteleridir (Karaküçük, 2016:132).

İnsanlar boş zamanlarında bulundukları ortamdan uzaklaşmak, gezme-görme, zevk alma, sağlıklı yaşama, farklı yaşantılar elde etme ve dinlenme gibi farklı amaçlarla, açık veya kapalı alanlarda, aktif-pasif katılımla şehir içinde ya da kırsal alanda çeşitli etkinliklere katılırlar. Rekreasyon, insanların boş zamanlarında katıldıkları bu etkinlikleri ifade eden bir kavramdır. Bireyler in günlük yaşamında rutin ve stresli iş yaşamı veya yaşam alanındaki çevrenin olumsuz etkilerinden kötü yönde etkilenen ruh ve beden sağlığına yeniden kavuşmak istemektedir. Bunun yanında bireyin tamamen çalışma ve zorunlu ihtiyaçlar için ayrılan zaman dışında kalan kendisine ait boş zamanda yapmaktan zevk alacağı, kişisel doyum sağlayacağ gönüllü olarak bireysel veya grup içinde seçerek yaptığı etkinliklere rekreasyon denir (Hacioğlu ve diğ., 2009: $30)$.

\subsection{Rekreasyona Duyulan Gereksinimin Nedenleri}

Rekreasyon: Kişinin boş zamanında bireysel ya da grupla yapmış olduğu herhangi bir etkinliktir. Rekreasyon gereksinimleri anlık ihtiyaçlardan değil çocukluktan itibaren yapılmış etkinliklerin, çevrenin ilgisinin, toplumsal süreçler ve kültür gibi etkenlerin rolünün olduğu bir süreçtir. Rekreasyon gereksinimleri karşılama deneyimi olarak tanımlanmaktadır. Her birey ruhsal gereksinimlerini giderme arayışındadır. Rekreasyon davranışları bireylerde iki güdüleme gücünün etkisi altındadır.

Günlük yaşamın tekdüzeliğinden, çevreden ve negatif ilişkilerden uzaklaşmaktır. Boş zaman yerinde ve değerli kullanılabildiğinde insana kendi kendine kalma, özgür olma, kendini bulma imkanı verir.

Rekreasyon etkinliklerine katılarak öz gerçekleştirim; etkin olma ve üstünlük kurma, mücadeleyi öğrenme, yaratıcılığı açığa çıkarma, rahatlama, kişisel toplumsal iletişim geliştirme gibi psikolojik ödül beklentisi ile güdülenmesini sağlar (Kılbaş, 2010:10-11).

Rekreasyon etkinliklerine katılımın sağladığı faydalar dikkate alındığında hem bireysel hem de toplumsal açıdan önemli bir unsur olduğu görülmektedir. İnsanoğlu fiziksel, ruhsal ve toplumsal açıdan rekreasyon faaliyetlerine ihtiyaç duymaktadır (Sevil, 2012:14). 


\subsection{Rekreasyon ve Turizm İlişkisi}

Turizm ve rekreasyon arasındaki ilişkiler belli olmamakla birlikte turizm ve rekreasyonel faaliyetler birbiri ile kaynaşmış durumdadır. Rekreasyon ve turizm talebi davranışlar yönünden ele alındığında iki talep tipinin birbirinden ayırt edilemeyecek kadar ilişkili olduğu görülmektedir. Turizm talebinin kaynak esaslı imkanlara yönelik olmasına karşın, rekreasyon talebinin kullanım esaslı imkanlara yönelik olması gibi, nisbi olarak yapılabilen bir ayrım dışında kullanılan imkanlar, katılınan aktiviteler ve taleplerin değişkenlik gösteren yapılarından dolayı her iki talep grubu da büyük benzerlik göstermektedir. Özellikle dışarıda yapılan rekreasyon faaliyetlerinin turizm olayı ile aynı zamanı, mekanları ve finans kaynaklarını kullanması bakımından ortak yönleri vardır. Bu yönü ile turizm ve rekreasyon ilişkisi çok yakındır ( Hacıoğlu, 2009: 5152).

Turizm ve rekreasyon ilişkisinde özellikle kırsal turizmin rekreasyonla yakın bir ilişkisi vardır. Açık alan rekreasyonunun ilgi alanına giren kırsal turizm günümüzde önemli oranda rağbet görmektedir. Turizm ve rekreasyon faaliyetleri insanlar için bir lüks değil aksine bir gereksinim haline gelmiştir. Nüfus artışı ve gelir düzeyinin yükselmesi bu gereksinimde önemli pay sahibidir. Bunun yanında hızlı kentleşme ve yeşil alanların hızla azalması şehir ortamından bunalan insanların turistik ve rekreasyon alanlarına talebini artırmıştır. Günümüzde büyük kentlerde yaşayan gençlerin ve eğitimli bireylerin kırsal turizme ve rekreasyona katılımında büyük bir artış olduğu görülmektedir. Doğal alanlara olan bu yoğun artış çevre sorunlarına neden olmuş ve giderek azalan doğal kaynakların korunmasına yönelik önlemlerin alınmasını gerekli kılmıştır (Sağcan, 1986:137-141).

Rekreasyon gereksinimleri anlık ihtiyaçlardan değil çocukluktan itibaren yapılmış etkinliklerin, çevrenin ilgisinin, toplumsal süreçler ve kültür gibi etkenlerin rolünün olduğu bir süreçtir. Rekreasyon gereksinimleri karşılama deneyimi olarak tanımlanmaktadır. Her birey ruhsal gereksinimlerini giderme arayışındadır. Rekreasyon davranışları bireylerde iki güdüleme gücünün etkisi altındadır.

Günlük yaşamın tekdüzeliğinden, çevreden ve negatif ilişkilerden uzaklaşmaktır. Boş zaman yerinde ve değerli kullanılabildiğinde insana kendi kendine kalma, özgür olma, kendini bulma imkanı verir.

Rekreasyon etkinliklerine katılarak öz gerçekleştirim; etkin olma ve üstünlük kurma, mücadeleyi öğrenme, yaratıcılığ 1 açığa çıkarma, rahatlama, kişisel toplumsal iletişim geliştirme gibi psikolojik ödül beklentisi ile güdülenmesini sağlar (Kılbaş, 2010:10-11).

\section{LITARETÜRDE ÜNIVERSITE ÖĞRENCILLERINIIN BOŞ ZAMAN FAALIYETLERINE YÖNELIK YAPILMIŞ BAZI ÇALIŞMALAR}

Bireylerin kişilik özelliklerinin boş zaman etkinliklerinin seçimi ve bu etkinliklere katılımda önemli bir etken olduğu görülmektedir.

Çinli üniversite öğrencilerin kişilik özelliklerinin boş zaman tatmini seviyeleri ve algılanan boş zaman memnuniyeti arasındaki ilişkiyi araştırmışlar, dışa dönük kişilik ile boş zaman katılımı ve boş zaman tatmini arasında pozitif bir ilişki olduğunu fakat nevrotik kişilik ile boş zaman katılım ve boş zaman tatmini arasında negatif bir ilişki olduğunu tespit etmişlerdir. Bulgulara göre dişa dönük kişilik özelliğinin sosyal aktiviteler başta olmak üzere birçok boş zaman aktivitesine katıldıkları ortaya çıkmaktadır. Ayrıca cinsiyetin kişilik ya da boş zaman memnuniyeti ile ilişkisinin olmadığını tespit etmişlerdir (Lu ve hu, 2005: 335-338).

Literatüre bakıldığında boş zaman memnuniyeti, boş zamana katılımdan elde edilen olumlu kişisel değerlendirme olarak ifade edilmektedir. Memnuniyet duygusu, bireylerin ihtiyaç duydukları veya şartlardan beklentilerine dayanır. Birçok çalışma, boş zaman katılımının bireylerin refahına olumlu katkıda bulunduğunu ortaya koymuştur. Boş zaman tutum, tatmin ve psikolojik iyi oluş arasında anlamlı bir ilişki olduğu kabul edilmektedir. Ayrıca boş zaman tatmini öğrencilerin stresini azaltarak ve sosyal aktiviteleri teşvik ederek yaşam doyumuyla yakından ilgilidir. Boş zaman aktivitesine aktif katılım psikolojik iyi oluşlarını olumlu yönde etkilemektedir. Bu tespitlerden hareketle; üniversite öğrencilerinin boş zaman tutumları (bilişsel, duyuşsal ve davranışsal) ile boş zaman tatmini ve psikolojik iyi oluş (stres, yalnızlık ve kişisel benlik saygısı) arasındaki ilişkiyi tanımlamak amacıyla yapmış oldukları çalışmada; boş zaman tutumu ile boş zaman memnuniyeti arasında pozitif bir ilişki bulmuşlardır (Sunyoong ve di ̌̆, 2015:70-76). Boş zaman etkinliklerine olumlu tutum ile katılan öğrencilerin boş zaman memnuniyeti ve kişisel benlik saygısı artarken stres ve yalnızlık duygusu azalarak psikolojik iyi oluşlarını artırmıştır. Boş zaman tatminin algılanan stres üzerinde olumlu bir etkiye sahip olduğu algılanan stresi azalttığı ayrıca yalnızlık ve benlik saygısı ile de olumlu bir ilişkisi olduğu görülmüştür. Boş zaman tutumunun bilişsel, duyuşsal ve davranışsal alt boyutlarında boş zaman katılımından kaynaklanan boş zaman tatmini üzerinde, boş zaman tatmininin de psikolojik iyi oluş üzerinde olumlu bir etkiye sahip olduğu görülmüştür. 
Çalışmalarında öğrencilerin boş zamanlarında katıldıkları fiziksel aktivitelerin kendilerinde olumlu duygu oluşturduğunu psikolojik iyi oluşlarını artırdığını bunun da stres ile başa çıkmaya olumlu etkileri olduğunu ifade etmişlerdir. Ayrıca katılımcılar fiziksel egzersizin stresin azaltılmasında arkadaşlarla buluşma, televizyon seyretme ya da eğlence gibi pasif boş zaman aktivitelerinden daha etkili olduğunu belirtmişlerdir (Jong-Ho ve Mc Kenzie, 2014: 42).

Boş zaman etkinlikleri, aktif dinlenme, rahatlama ve günlük yaşamın olası olumsuz sonuçlarından kaçınmaya katkı sağlar. Ayrıca zihinsel, fiziksel, sosyal ve duygusal sağlık ve esenliğe katkıda bulunur. Bilişsel düşüş ve kardiyovasküler hastalıkların önlenmesine ek olarak, arkadaşlıklar geliştirmek ve stres atmak için zengin bir içerik sağlar (Caldwell, Linda L., 2005:23).

Üniversitelerindeki lisans öğrencileri arasındaki boş zaman, fiziksel aktivite katılımına yönelik tutum, özyeterlik ve motivasyonun etkilerini araştırmışlardır. Motivasyon ve öz-yeterlik faktörlerinin, boş zamanın fiziksel aktivite katılımının en iyi belirleyicileri olduğunu göstermiştir. Fiziksel aktivite için yüksek öz-yeterlik ve motivasyonun, lisans öğrencileri arasında boş zamanlarında fiziksel aktiviteye katılım oranını artırdığını göstermektedir. Tutum ve öz-yeterlik kombinasyonunun, yerel kamu üniversitelerindeki öğrenciler arasında fiziksel aktivite katılımı için motivasyon üzerinde doğrudan ve dolaylı etkileri olduğunu ortaya koymuştur. Fiziksel aktiviteye karşı tutum söz konusu olduğunda, aradaki değişkenin (motivasyon) dolaylı etkileri, boş zamanın fiziksel aktivite katılımı üzerindeki doğrudan etkilerden daha güçlüdür. Ayrıca yükseköğretim öğrencilerinin fiziksel aktivite için öz-yeterlik inanc1, boş zamanlarında fiziksel aktivitelere daha sık katılmalarını etkilemektedir (Lim, khong ve kalsom, 2010:40-42).

Boş zamanlarda fiziksel aktivite katılımının yüksek öz yeterlilik, motivasyon ve olumlu tutumla doğrudan ilişkili olduğunu bulmuşlardır. Öğrencilerin boş zamanlarında fiziksel aktivite katılımının tutumlarını olumlu yönde etkilemiştir. Ayrıca boş zamanlarda fiziksel aktivite katılım oranlarını, yüksek öz yeterlilik ve motivasyonun artırdığını tespit etmiştir (Limkhong chiu, 2009: 9-10).

Zorunlu toplum hizmetlerinin hem de sivil faaliyetlere gönüllü katılımın, üniversite öğrencilerinin yaşamlarında kişisel gelişimlerine yardımcı olabileceğini göstermiştir. Ayrıca gönüllü sivil faaliyetlere katılımın ve boş zaman memnuniyetinin strese bağlı büyümeyle olumlu yönde ilişkili olduğunu tespit etmiştir (Sanghee ve diğ., 2012: 445-446).

Öğrencilerin boş zaman değerlendirme beklentilerinin, eğlence aktivitelerine öğrenci katılımı ile önemli ölçüde ilişkili olduğunu doğrulamıştır. Stres ile boş zaman katılımı arasında doğrudan bir ilişki bulunamasa da boş zaman faydaları ilişki kurulmasında önemli bir araç olmuştur. Öğrenciler boş zaman erkinliklerine katılımın eğitsel, sosyal, fizyolojik veya estetik açıdan yararlı olabileceğine inandıkları zaman, stresle başa çıkmak için boş zaman aktivitelerine katılma olasılıkları artmaktadır. Duygusal rahatlama arayan öğrenciler, film izlemek ve müzik dinlemek gibi pasif medya temelli etkinliklere katılmaya eğilimlidirler. Fiziksel uygunluk ve başkalarıyla iyi ilişkiler geliştirmek isteyen öğrenciler spora yüksek katılım sağlamışlardır. Sosyalleşme faaliyetlerine sık katılan öğrenciler başkalarıyla ilişkilerin geliştirilmesinin etkili bir yolu olduğuna inanmalarıdır. Stresle başa çıkmak için boş zaman aktivitesine katılımın yararı konusunda farkındalığ artırmak için daha fazla bilgilendirme yapılmalı programlar tasarlanmalıdır (Xinran, Y.Lehto ve diğ., 2014: 211-213).

Üniversite öğrencilerinin sosyalleşmesinde önemli bir yeri olan, gönüllü toplumsal faaliyetlere katılımlarındaki en büyük engelin yapısal kısıtlamalar (zaman, para, ulaşım vb. eksikliği) olduğunu belirtmişlerdir. Öğrenciler özellikle zamanın yetersiz olduğunu ifade etmişlerdir. Bireyin boş zaman faaliyeti olan gönüllü organizasyonlara katılma kararında motivasyon ve kısıtlamaların rolü olduğu görülmüştür. Kişiler arası ve yapısal kısıtlamalar artıkça öğrenciler insanlara ve topluma hizmet etmek için motivasyonlarının azaldığını ifade etmişlerdir (Richard L.Gage ve Brijesh Thapa, 2012:424-425).

Yapmış olduğu çalışmada, boş zaman faaliyetlerine katılmada kadın ve erkekler arasında farklılıklar olduğunu tespit etmiştir. Boş zaman faaliyetlerine katılmada kadınlar erkeklere oranla daha fazla yapısal engelle karşılaşmaktadırlar (Hudson, 2000:363-368).

Demografik özelliklerden cinsiyet değişkeni boş zaman katılımını ve memnuniyetini etkilemezken yaş, eğitim ve gelir bazı önemli korelasyonlar göstermiştir. Daha genç daha iyi eğitimli ve daha varlıklı insanlar boş zaman aktivitelerine daha fazla katıldıklarını ve daha fazla boş zaman tatmini yaşadıklarını ifade etmişlerdir (Lou ve Shu-Fang, 2009: 6).

Üniversite öğrencilerinin boş zamanlarına yönelik tutumlarını araştırmışlar öğrencilerinin günlük 4-5 saat boş zamanları olduğu, boş zamanlarının 1-2 saatini turizmle ilgili etkinliklere katılarak geçirdikleri, turizm faaliyeti olarak en fazla gezme etkinliğinde bulundukları görülmüştür. Yapılan diğer boş zaman etkinliği olarak spor ve müzik ile ilgilenme gelmektedir. Öğrenciler, hoşlandıkları farklı boş zaman etkinliklerinin 
motivasyonlarını artırdığını ifade etmişlerdir. Boş zaman faaliyetlerinin kendilerini iyi hissettirdiğini, gelişimlerine faydalı olduğunu belirtmişlerdir (Binbaşığlu ve Tuna, 2014: 89-90).

Rekreasyonel aktivitelere katılımı engelleyen nedenler olarak; Ailelerine zaman ayırma, okul programlarının uygun olmaması, tesis yetersizliği, kendisini yorgun hissetme, etkinlikler hakkında yeterli bilgiye sahip olmama boş zaman etkinliklerine katılımda önemli engeller olarak belirtilmiştir. Öğrencilerin çoğunun haftada 11 ile 15 saat boş zamanlarının olduğu, boş zamanlarında en fazla sosyal etkinlikleri tercih ettikleri görülmüştür (Karaçar ve Pasl1, 2014:32-35).

Üniversite öğrencilerinin spor ve sosyal etkinliklere doğrudan katıldıkları, sanat ve kültür faaliyetlerine de genelde pasif olarak katılım sağladığı görülmüştür. Öğrencilerin boş zaman etkinliklerine ayda ortalama 3-4 kez katıldıkları görülmüştür. Ayrıca etkinliklere katılım oranlarındaki artışla birlikte algılanan özgürlük düzeylerinde artış göstermiştir. Öğrencilerin serbest zamanda algılanan özgürlük puanlarının ortalama değerlerde olduğu görülmüştür ayrıca cinsiyet değişkenine göre algılanan özgürlük düzeyinde anlamlı bir farklılığın olmadığı tespit edilmiştir. Boş zaman etkinliklerine aktif katılımın algılanan özgürlük puanlarını artırdığı görülmüştür (Yerlisu Lapa ve Ağyar, 2012:28-30).

Kız ve erkek üniversite öğrencilerinin serbest zaman tatmin düzeylerinin düşük olduğu fakat cinsiyete göre bir fark olmadığını tespit edilmiştir. Ayrıca gelirin bireylerin serbest zaman etkinliklerine katılımını etkilediği, gelirdeki artışın serbest zaman tatminlerini de artırdığı görülmektedir (Ardahan ve Yerlisu Lapa, 2010:133-134).

Öğrenciler boş zaman etkinliklerine genelde arkadaşlarıyla katıldıklarını bu etkinlikleri eğlenceli oldugu için tecih ettiklerini ifade etmişlerdir. Rekreasyon faaliyetlerine haftada en fazla 10 saate kadar katılım gösterdikleri görülmektedir. Yine haftada en fazla 3-4 kez boş zaman etkinliklerine katıldıklarını ifade etmişlerdir. Öğrencilerin aktif olarak spor aktivitelerine ve sosyal etkinliklere katıldıkları, kültürel etkinliklere ise seyirci olarak katılım sağladıkları tespit edilmiştir (Tercan Kaas, 2015:574).

Üniversite öğrencilerinin rekreasyon faaliyetlerine katılımını etkileyen unsurların kişilik, alanların durumu, olumsuz içsel deneyimler, ulaşım sorunları, zaman yetersizliği, iş ile ilgili sorumluluklar olduğunu bu yüzden öğrencilerin rekreasyon etkinliklerine katılım konusunda isteksiz olduklarını belirlemişlerdir. Bireyin kendisine olan güveni sağlıklı ve kendisini iyi hissetmesi rekreasyon etkinliklerine katılımı olumlu yönde etkilediği görülmektedir. Ayrıca öğrencilerin kendilerine ve yeteneklerine güvenmemeleri, olumsuz deneyimler yaşamaları, rekreasyon etkinliklerine yönelik tutumlarını negatif yönde etkilemektedir (Tütüncü ve diğ., 2011:81-82).

Üniversite ögrencilerin haftada ortalama 3 ile 6 saat boş zaman imkanlarının oldukları görülürken öğrencilerin rekreasyon faaliyeti olarak fiziksel aktiviteye yeterli düzeyde katılmadığını tespit etmişlerdir. Rekreasyon etkinlikleri ile ilgili bilgi eksikliği kadınlarda erkeklerden fazla olduğu görülmüştür (Çoruh ve Karaküçük, 2014:859-860).

Öğrencilerinin \%36'sının boş zamanlarını evde geçirdikleri \%19'unun boş zamanlarında sportif etkinlikleri, \%4'ü de boş zamanlarında turizm faaliyetlerini tercih etmişlerdir. Ayrıca gelir seviyesinin katıldıkları boş zaman etkinliklerinin çeşidini ve etkinliklere katılımlarını olumlu ve olumsuz yönde etkilediği görülmektedir. Öğrencilerin boş zaman etkinlikleri ve faydaları hakkında yeterli bilgiye sahip olmadıkları, etkinliklere katılımda arkadaş ve zaman eksikliği çektikleri görülmüştür (Ekinci ve diğ., 2014:9-10).

Ankara' daki üniversite öğrencilerinin boş zaman etkinliklerine katılabilmek için yeterli boş zamana sahip olduğunu ayrıca cinsiyet ve gelirin boş zamanın değerlendirilmesini etkilediği görülmektedir. Bireylerin boş zaman faaliyetlerinin seçiminde ve katılımlarında, yaş, cinsiyet, kültür gibi birçok neden etkili olmaktadır. Öğrenciler boş zamanlarında; müzik dinleme, spor yapma, kitap ve gazete okuma, sinemaya gitme, fuar ve parkları gezme, arkadaş ziyareti, ve televizyon izleme gibi etkinlikleri tercih ettikleri görülmektedir. Ayrıca zaman yetersizliği, ekonomik sebepler, ruh halinin iyi olmaması, organizasyonların yetersizliği, gibi nedenlerin öğrencilerin rekreasyon faaliyetlerine katılmasını kısıtlayan nedenler olduğu görülmüştür (Somuncu ve diğ., 2015:312-314).

Hazırlık öğrenimi gören bayan üniversite öğrencilerinin boş zaman değerlendirmelerini engel olarak tesislerin yetersizliği, bilgisizlik, psikoloji, zaman yetersizliği, arkadaş gurubunun ilgisizliği gibi etkenler olduğunu belirtmişlerdir. Ayrıca kız öğrenciler, refah seviyelerinin rekreasyonel etkinliklere katılımdaki engellerden biri olduğunu ifade etmişlerdir (Bulut ve Koçak, 2016:66-69).

Öğrencilerinin boş zaman faaliyetlerine katılımın da üniversite yerleşkesinin sosyal imkanlarının kısıtlı olduğu buna bağlı olarak ta ders dışında boş zamanlarını yerleşke içerisinde geçirmediklerini ifade etmişlerdir. Kampüs alanı yeterli olanağa sahip olmadığından boş zamanlarını yeterli bir şekilde değerlendiremediklerini belirtmişlerdir (Kılıç ve Şener, 2013:226). 
Üniversite kampüsleri, eğitim ve bilimsel çalışmalarının yürütülmesi yanı sıra rekreasyonel, sosyal, ekolojik ve ekonomik çok yönlü işlevleri ile önemli yaşam merkezleridir. Bununla birlikte kentlerin de önemli yeşil alanları olarak görülür. Bu bağlamda üniversite yerleşkeleri, akademik ve idari personel ve öğrenciler, veliler, şehrin insanları için sosyal, kültürel, fiziksel, zihinsel ve düşünsel gelişmeyi sağlaması açısından önemli rekreasyonel alanlardır (Gül ve diğ., 2016:36-40).

\section{METEDOLOJI}

\subsection{ARAŞTIRMANIN YÖNTEMI}

Bu bölümde araştırmanın yöntemi, araştırmanın evren ve örneklemini, verileri toplama araçlarını, verilerin toplanmasını ve verilerin analizinde kullanılan istatistiksel konulara yer verilmiştir.

$\mathrm{Bu}$ araştırmayla ÜNIKOP kapsamındaki üniversitelerin turizm fakültelerinde öğrenim görmekte olan öğrencilerin boş zaman etkinliklerine karşı tutumlarının belirlenmesi, boş zamanlarını nasıl değerlendirdikleri ve boş zaman etkinliklerine ne sıklıkla katıldıkları, boş zaman tutumlarında cinsiyet, sosyo-ekonomik durum, ailenin eğitim durumu, kalınan yer ve aile yaşam yerinin etkisinin olup olmadığının tespiti amaçlanmıştır.

Araştırma; kapsam ve yöntemin belirlenmesi, konuya ilişkin bilgilerin toplanması, literatür taraması ve anket formu uygulanacak şekilde betimsel yöntemle yürütülmüştür. KOP bölgesi üniversiteler birliği (ÜNIKOP) on bir devlet ve iki vakıf üniversitesi olmak üzere on üç üniversiteden oluşmaktadır. Bu üniversitelerden Necmettin Erbakan Üniversitesi Turizm Fakültesi, Selçuk Üniversitesi Turizm Fakültesi, Aksaray Üniversitesi Turizm Fakültesi ve Nevşehir Hacı Bektaş Veli Üniversitesi Turizm Fakültesi olmak üzere dört üniversitede turizm fakültesi bulunmaktadır. Araştırma 2017-2018 eğitim-öğretim döneminde dört üniversitenin turizm fakültelerinde öğrenim görmekte olan 4.sınıf öğrencileriyle sinırlıdır.

\subsection{Evren ve Örneklem}

KOP Bölgesi Üniversiteleri Turizm Fakültelerinde öğrenim gören bireylerin boş zamana yönelik olan bakış açılarını inceleyen bu araştırmada betimsel ve taramaya yönelik bir yöntem uygulanmış ve araştırma iki aşamadan oluşmuştur. Konu hakkında teorik bir çerçeve oluşturması açısından, çalışmanın ilk aşamasında amaca uygun mevcut bilgiler ilgili literatürün taranmasıyla sistematik bir şekilde verilmiştir. Araştırmanın ikinci aşaması olan uygulama aşamasında ise amaca ulaşmak için anket örneklem grubuna uygulanmıştır. Araştırmanın evrenini KOP bölgesi üniversiteleri turizm fakültesi öğrencileri oluşturmakta olup, örneklem olarak Necmettin Erbakan Üniversitesi, Selçuk Üniversitesi, Aksaray Üniversitesi, Nevşehir Hacı Bektaş Veli Üniversiteleri'nin turizm fakültelerinde öğrenim gören dördüncü sınıf öğrencileri oluşturmaktadır. Anket formu örneklem olarak alınan bu dört üniversitenin turizm fakültesi 4. sınıfında 2017-2018 öğretim y1lında öğrenim görmekte olan $218 \mathrm{k1z}$ ve 230 erkek olmak üzere 448 öğrenciye uygulanmıştır. Bu anketlerden 211 k1z ve 208 erkek olmak üzere 419'u öğrenciler tarafindan doldurulmuştur. 29 anket değerlendirmeye alınmamıştır.

\subsection{Veri Toplama Araçları}

Çalışmada, öğrencilerin boş zaman tutum düzeylerini ölçebilmek için "Boş Zaman Tutum Ölçeği", kullanılmıştır. Öğrencilerin demografik özellikleri hakkında bilgi toplamak amacıyla da "Kişisel Bilgi Formu" kullanılmıştır.

\subsection{Kişisel Bilgi Formu}

Bağımsız değişkenler ile ilgili veri toplamak amacıyla geliştirilen bilgi formu 2 bölüm ve 13 sorudan oluşmaktadır. Birinci bölüm öğrencilerin kişisel bilgilerinden; Cinsiyet, aylık gelir durumu, üniversite adı, anne eğitim düzeyi, baba eğitim düzeyi, üniversite eğitiminde nerede kaldığı, ailenin yaşadığı yer gibi sorulardan oluşmuştur. İkinci bölümde boş zaman ile ilgili kişisel ve genel bilgileri belirleyecek ifadelere yer verilmiştir. Günlük kaç saat boş zamanları olduğu, boş zamanlarının yeterliliği, boş zamanlarını olumlu kullanılıp kullanılmadığ zaman imkânı sunup sunmadığ 1 ve boş zaman faaliyetlerine kimlerle katıldığını belirlemeye yönelik sorulardan oluşmaktadır.

\subsection{Boş Zaman Tutum Ölçeği}

Veri toplama aracının üçüncü bölümünde ise boş zaman tutum ölçeği kullanılmıştır. Ragheb Beard tarafindan 1982'de geliştirilen Leisure Attitude Scale (Boş Zaman Tutum Ölçeği)'1n Türkçe uyarlaması Akgül ve Gürbüz tarafından yapılmıştır. Ölçek bilişsel, duyuşsal ve davranışsal olmak üzere 3 alt boyuttan ve her bir boyutta 12 madde olmak üzere toplam 36 maddeden oluşmaktadır. Anketten en düşük 36 puan en yüksek 180 
puan alınmaktadır. Katılımcıların boş zaman aktivitelerine yönelik tutumları 5'li Likert tipi ölçek üzerinden değerlendirilmekte olup ifadeler; Kesinlikle katılmıyorum - Katılmıyorum - Kararsızım - Katılıyorum Kesinlikle katılıyorum şeklinde cevaplanmaktadır. (Akgül ve Gürbüz, 2011: 41) Türk üniversite öğrencilerinin boş zamana yönelik tutumlarını belirlemek için ölçeğin geçerli ve güvenilir olduğunu belirlemişlerdir. Buna göre; Ölçeğin KMO değeri 935 bulunmuştur. Ölçeğin iç tutarlılık katsayısı cronbach alpha değeri Duyuşsal = 92, Bilişsel $=81$, Davranışsal $=91$ olarak bulunmuştur. Ölçeğin toplam güvenilirlik katsayısı 97 oranında yüksek güvenilir bulunmuştur. Ölçeğin maddelerinin birbiriyle tutarlı ve aynı özelliği ölçmeyi hedefleyen maddelerden olduğu görülmektedir.

\subsection{Verilerin Toplanması ve Analizi}

KOP bölgesi üniversitelerinden turizm fakültesi bulunan üniversitelerin fakülte yetkilileri ile görüşüldükten sonra anket, araştırmacı eşliğinde Necmettin Erbakan Üniversitesi, Selçuk Üniversitesi, Aksaray Üniversitesi, Nevşehir Hacı Bektaş Veli Üniversiteleri’nin turizm fakültesi dördüncü sınıfında öğrenim gören öğrenciler tarafindan doldurulmuştur. Uygulama öncesinde ölçekler hakkında öğrencilere açıklamada bulunulmuş ve öğrencilerin ölçeklerle alakalı sorularına cevap verilmiştir. Çalışmaya katılımın gönüllülük esasına bağlı olduğu belirtilip, soruları içtenlikle yanıtlamaları istenmiştir. Öğrencilere kimlik bilgilerini yazmalarının gerekli olmadığı belirtilmiş̧ir.

Verilerin analizinde SPSS 20 paket programı kullanılmıştır. Veri analizinde yüzde, ortalama, standart sapma analizlerinden yararlanılmıştır. Boş zaman tutumu farklılığını ortaya koymak amacı ile $t$ testi ve ANOVA kullanılmıştır. Yapılan analizler sonucunda anlamlı farklılığın ortaya çıkması durumunda, farklılığın hangi gruplar arasında olduğunu belirlemek için varyansların homojenliği kontrol edilmiş olup, varyansların homojen olması durumunda çoklu karşılaştırma testlerinden tukey testi, kullanılmıştır. Verilerin istatistiksel analizinde ve yorumlarda, $\mathrm{p}<0,05$ anlamlılık düzeyi dikkate alınmıştır.

\section{BULGULAR}

Tablo 1. Araştırma Katılımcılarının Demografik Özellikleri

\begin{tabular}{llcccc}
\hline & \multicolumn{3}{c}{ Erkek } & \multicolumn{3}{c}{ Kadın } \\
\hline Değiş̧kenler & & $\begin{array}{c}\text { Frekans } \\
\text { (f) }\end{array}$ & Yüzde (\%) & $\begin{array}{c}\text { Frekans } \\
\text { (f) }\end{array}$ & Yüzde (\%) \\
\hline \multirow{5}{*}{ Üniversite } & Selçuk & 103 & 49,5 & 54 & 25,6 \\
& Necmettin & 42 & 20,2 & 58 & 27,5 \\
& Aksaray & 19 & 9,1 & 13 & 6,2 \\
& Nevşehir & 44 & 21,2 & 86 & 40,8 \\
\hline \multirow{5}{*}{ Gelir Durumu } & $1-500$ & 59 & 28,4 & 84 & 39,8 \\
& 501-1000 & 66 & 31,7 & 83 & 39,3 \\
& $1001-1500$ & 41 & 19,7 & 26 & 12,3 \\
& $1501-2000$ & 25 & 12,0 & 10 & 4,7 \\
& 2001 ve üzeri & 17 & 8,2 & 8 & 3,8 \\
\hline \multirow{5}{*}{ Anne öğrenim } & İlkokul/ortaokul & 135 & 64,9 & 154 & 73,0 \\
& Lise & 48 & 23,1 & 39 & 18,5 \\
& Lisans & 22 & 10,6 & 18 & 8,5 \\
& Lisansüstü & 3 & 1,4 & - & - \\
\hline \multirow{5}{*}{ Baba öğrenim } & İlkokul/ortaokul & 105 & 50,5 & 128 & 60,7 \\
& Lise & 68 & 32,7 & 57 & 27,0 \\
& Lisans & 32 & 15,4 & 24 & 11,4 \\
& Lisansüstü & 3 & 1,4 & 2 &, 9 \\
& Toplam & 208 & 100,0 & 211 & 100,0 \\
\hline
\end{tabular}


Tablo2. Öğrencilerin Anne Öğrenim Durumu Tablosu

\begin{tabular}{|l|l|c|c|c|}
\hline \multirow{4}{*}{ BíLIŞSEL } & & $\mathrm{n}$ & $\mathrm{X}$ & Standart Sapma \\
\hline \multirow{5}{*}{ DUYUŞSAL } & İlk ve orta okul & 289 & 3,96 & 0,82 \\
\cline { 2 - 5 } & Lise & 87 & 3,92 & 0,84 \\
\cline { 2 - 5 } & Lisans & 40 & 3,70 & 0,98 \\
\cline { 2 - 5 } & Lisans üstü & 3 & 2,86 & 0,31 \\
\cline { 2 - 5 } & Toplam & 419 & 3,92 & 0,85 \\
\hline \multirow{5}{*}{ DAVRANIŞSAL } & İlk ve orta okul & 289 & 3,90 & 0,76 \\
\cline { 2 - 5 } & Lise & 87 & 3,86 & 0,80 \\
\cline { 2 - 5 } & Lisans & 40 & 3,64 & 0,79 \\
\cline { 2 - 5 } & Lisans üstü & 3 & 2,58 & 1,10 \\
\cline { 2 - 5 } & Toplam & 289 & 3,64 & 0,78 \\
\hline & İlk ve orta okul & 87 & 3,57 & 0,75 \\
\cline { 2 - 5 } & Lise & 40 & 3,58 & 0,84 \\
\cline { 2 - 5 } & Lisans & 3 & 2,41 & 0,69 \\
\cline { 2 - 5 } & Lisans üstü & 419 & 3,61 & 1,23 \\
\cline { 2 - 5 } & Toplam & 3,86 & 0,77 \\
\hline
\end{tabular}

Öğrencilerin anne öğrenim durumu tablosuna bakıldığında boş zaman tutum ölçeği alt boyutlarında en yüksek ortalamada ilk-orta okul mezunu en düşük ortalamada lisansüstü mezunlarının olduğu görülmektedir.

Tablo 3. Anne Öğrenim Durumu Anova Sonuçları

\begin{tabular}{|c|c|c|c|c|c|c|}
\hline & Varyansın Kaynağı & Sum of Squares & $\mathrm{df}$ & Mean Square & $\mathrm{F}$ & $\mathrm{p}$ \\
\hline \multirow[t]{3}{*}{ BİLISSSEL } & Gruplar arası & 5,776 & 3 & 1,925 & \multirow[t]{3}{*}{2,686} & \multirow[t]{3}{*}{0,046} \\
\hline & Grup içi & 297,459 & 416 &, 717 & & \\
\hline & Toplam & 303,235 & 419 & & & \\
\hline \multirow[t]{3}{*}{ DUYUŞSAL } & Gruplar arası & 7,359 & 3 & 2,453 & \multirow[t]{3}{*}{4,068} & \multirow[t]{3}{*}{0,007} \\
\hline & Grup içi & 250,271 & 416 & ,603 & & \\
\hline & Toplam & 257,630 & 419 & & & \\
\hline \multirow[t]{3}{*}{ DAVRANIŞSAL } & Gruplar arası & 4,701 & 3 & 1,567 & \multirow[t]{3}{*}{2,610} & \multirow[t]{3}{*}{0,051} \\
\hline & Grup içi & 249,153 & 416 & ,600 & & \\
\hline & Toplam & 253,854 & 419 & & & \\
\hline
\end{tabular}

Anne öğrenim durumu değişkenine göre, bilişsel ve duyuşsal alt boyutlardaki fark istatistiksel olarak anlamlı bulunurken, davranışsal alt boyutta istatistiksel olarak anlamlı bir fark bulunmadı $(p<0,05)$. Farkın hangi gruplardan kaynaklandığına ise Tukey-testi ile bakılmış ve aşağıda tabloda verilmiştir.

Tablo 4. Baba Öğrenim Durumu Anova Sonuçları

\begin{tabular}{|l|l|c|c|c|c|c|}
\hline \multicolumn{9}{|c|}{ ANOVA } \\
\hline \multirow{3}{*}{ BİLIŞSEL } & Sum of Squares & df & Mean Square & F & $\mathrm{p}$ \\
& Gruplar aras1 & 2,396 & 3 &, 799 & & \\
\cline { 2 - 6 } & Grup içi & 300,839 & 416 &, 725 & \multirow{3}{*}{1,102} & 0,348 \\
\cline { 2 - 5 } & Toplam & 303,235 & 419 & & & \\
\hline DUYUŞSAL & Gruplar aras1 & 1,852 & 3 &, 617 & 1,001 & 0,392 \\
\hline
\end{tabular}




\begin{tabular}{|l|l|c|c|c|c|c|}
\hline & Grup içi & 255,778 & 416 &, 616 & & \\
\cline { 2 - 5 } & Toplam & 257,630 & 419 & & & \\
\hline \multirow{3}{*}{ DAVRANIŞSAL } & Gruplar aras1 & 2,341 & 3 &, 780 & \multirow{3}{*}{1,287} & \multirow{2}{*}{0,278} \\
\cline { 2 - 5 } & Grup içi & 251,513 & 416 &, 606 & & \\
\cline { 2 - 5 } & Toplam & 253,854 & 419 & & & \\
\hline
\end{tabular}

Baba öğrenim durumu değişkenine göre boş zaman tutum ölçeği alt boyutlarında anlamlı bir fark bulunmadı $(\mathrm{p}>0,05)$.

Tablo 5. Gelir Durumu Anova Sonuçları

\begin{tabular}{|c|c|c|c|c|c|c|}
\hline \multicolumn{7}{|c|}{ ANOVA } \\
\hline & & $\begin{array}{l}\text { Sum of } \\
\text { Squares }\end{array}$ & df & $\begin{array}{l}\text { Mean } \\
\text { Square }\end{array}$ & $\mathrm{F}$ & $\mathrm{p}$ \\
\hline \multirow[t]{3}{*}{ BİLİŞSEL } & Gruplar arası & 4,422 & 4 & 1,105 & 1,532 & 0,192 \\
\hline & Grup içi & 298,813 & 415 &, 722 & & \\
\hline & Toplam & 303,235 & 419 & & & \\
\hline \multirow[t]{3}{*}{ DUYUŞSAL } & Gruplar arası & 5,598 & 4 & 1,399 & 2,299 & 0,058 \\
\hline & Grup içi & 252,032 & 415 & ,609 & & \\
\hline & Toplam & 257,630 & 419 & & & \\
\hline \multirow[t]{3}{*}{ DAVRANIŞSAL } & Gruplar arası & 4,018 & 4 & 1,004 & 1,665 & 0,157 \\
\hline & Grup içi & 249,836 & 415 & ,603 & & \\
\hline & Toplam & 253,854 & 419 & & & \\
\hline
\end{tabular}

Gelir durumu değişkenine göre boş zaman tutum ölçeği alt boyutlarında anlamlı bir fark bulunmamıştır $(\mathrm{p}>005)$.

Tablo 6. Kaldığı yer Anova sonuçları

\begin{tabular}{|c|c|c|c|c|c|c|}
\hline \multicolumn{7}{|c|}{ ANOVA } \\
\hline & & $\begin{array}{l}\text { Sum of } \\
\text { Squares }\end{array}$ & df & $\begin{array}{l}\text { Mean } \\
\text { Square }\end{array}$ & $\mathrm{F}$ & $\mathrm{p}$ \\
\hline \multirow[t]{3}{*}{ BİLİŞSEL } & Gruplar arası & 6,853 & 5 & 1,371 & 1,910 & 0,092 \\
\hline & Grup içi & 296,382 & 414 & ,718 & & \\
\hline & Toplam & 303,235 & 419 & & & \\
\hline \multirow[t]{3}{*}{ DUYUŞSAL } & Gruplar arası & 7,165 & 5 & 1,433 & 2,363 & $\mathbf{0 , 0 3 9}$ \\
\hline & Grup içi & 250,465 & 414 & 0,606 & & \\
\hline & Toplam & 257,630 & 419 & & & \\
\hline \multirow[t]{3}{*}{ DAVRANIŞSAL } & Gruplar arası & 3,727 & 5 & 0,745 & 1,231 & 0,294 \\
\hline & Grup içi & 250,127 & 414 & 0,606 & & \\
\hline & Toplam & 253,854 & 419 & & & \\
\hline
\end{tabular}

Öğrencilerin kaldığı yer değişkenine göre boş zaman tutum ölçeği alt boyutlarından duyuşsal boyutta anlamlı bir fark bulunmuştur $(\mathrm{p}<005)$. Farkın hangi gruplardan kaynaklandığına ise Tukey-testi ile bakılmış ve aşağıda tobloda verilmiştir. 
Tablo 7. Cinsiyetlere Göre Boş Zaman Tutum Ölçeği Alt Boyutları ve Toplam Puanın Bağımsız (Independent) t- Testi Ile Analizi

\begin{tabular}{lcccccc}
\hline \multirow{2}{*}{ Duyuşsal } & Cinsiyet & $\mathrm{N}$ & Ortalama(X) & Standart Sapma (SS & $\mathrm{t}$ testi & $\mathrm{p}$ \\
& Erkek & 209 & 47,30 & 11,33 & & \\
& Kadın & 210 & 53,28 & 8,12 & -6.20 & $0.00^{*}$ \\
Bilişşel & Erkek & 209 & 43,96 & 11,38 & & \\
& Kadın & 210 & 50,13 & 7,82 & -6.48 & $0.00^{*}$ \\
& Erkek & 209 & 41,65 & 10,31 & & \\
Davranışsal & Kadın & 210 & 45,05 & 7,93 & -3.78 & $0.00^{*}$ \\
& Erkek & 209 & 132,91 & 29,82 & & \\
Toplam & Kadın & 210 & 148,47 & 20,65 & -6.19 & $0.00^{*}$ \\
\hline${ }^{* p} \leq 0.05$ & & & & & &
\end{tabular}

Cinsiyetlere göre Boş zaman tutum ölçeği alt boyutları olan Duyuşsal $(\mathrm{t}=-6.20, \mathrm{p}=0.00)$, Bilişsel $(\mathrm{t}=-6.48$, $\mathrm{p}=0.00)$, Davranışsal $(\mathrm{t}=-3.78, \mathrm{p}=0.00)$ ve toplam ölçek puanında $(\mathrm{t}=-6.09, \mathrm{p}=0.00)$ istatistiksel olarak anlamlı farklılıklara rastlanmıştır.

Tablo 8. Erkek ve Kadın Katılımcıların Üniversitelere Göre Boş Zaman Tutum Ölçeği Alt Boyutları ve Toplam Skorunun Ortalama ve Standart Sapmaları

\begin{tabular}{|c|c|c|c|}
\hline Üniversite & & Cinsiyet & \\
\hline & & Erkek & Kadın \\
\hline & & Ort. \pm SS & Ort. \pm SS \\
\hline \multirow[t]{4}{*}{ 1.Selçuk Üniv. } & Duyussal & $44,46 \pm 11,9$ & $53,45 \pm 7.8$ \\
\hline & Bilissel & $40,42 \pm 11.9$ & $49,22 \pm 8.1$ \\
\hline & Davranıssal & $40,12 \pm 11,4$ & $45,20 \pm 8.8$ \\
\hline & Toplam Puan & $125,01 \pm 32.4$ & $147,88 \pm 21.8$ \\
\hline \multirow[t]{4}{*}{ 2.Necmettin Er. } & Duyussal & $51,30 \pm 7.2$ & $53,9 \pm 6.6$ \\
\hline & Bilissel & $49,64 \pm 7.5$ & $50,89 \pm 5.8$ \\
\hline & Davranıssal & $44,71 \pm 7.7$ & $46,19 \pm 6.8$ \\
\hline & Toplam Puan & $145,66 \pm 17.9$ & $151,03 \pm 16.6$ \\
\hline \multirow[t]{4}{*}{ 3.Aksaray } & Duyussal & $49,52 \pm 13.70$ & $53,00 \pm 10.4$ \\
\hline & Bilissel & $44,78 \pm 12.9$ & $48,61 \pm 11, .6$ \\
\hline & Davranıssal & $43,05 \pm 12.5$ & $45,23 \pm 9.7$ \\
\hline & Toplam Puan & $137,36 \pm 38.5$ & $146,84 \pm 28.8$ \\
\hline \multirow[t]{4}{*}{ 4.Nevşehir } & Duyussal & $49,15 \pm 10.6$ & $52,69 \pm 8.8$ \\
\hline & Bilissel & $46,45 \pm 9.4$ & $50,41 \pm 8.2$ \\
\hline & Davranıssal & $41,70 \pm 8.0$ & $44,27 \pm 7.7$ \\
\hline & Toplam Puan & $137,31 \pm 22.8$ & $147,39 \pm 21.1$ \\
\hline \multirow[t]{4}{*}{ Toplam } & Duyussal & $47,30 \pm 11.3$ & $53,24 \pm 8.12$ \\
\hline & Bilissel & $43,96 \pm 11.3$ & $50,13 \pm 7.8$ \\
\hline & Davranıssal & $41,65 \pm 10.3$ & $45,09 \pm 7.9$ \\
\hline & Toplam Puan & $132,91 \pm 29.8$ & $148,47 \pm 20.6$ \\
\hline
\end{tabular}


Tablo 9. Two-way ANOVA (İki yönlü ANOVA) Testi İle Analizi ve Tukey Post-Hoc Testi

\begin{tabular}{|l|c|c|r|c|r|c|c|r|}
\hline & Cinsyet & & Değer & F & Hipotez df(fark) & Hata df & Sig. & Post-hoc \\
\hline Üniversite & Erkek & Wilks' Lambda &, 877 & 3,036 & 9,000 & 491,766 & $0,002^{*}$ & $1-2,1-4$ \\
\hline Üniversite & Kadın & Wilks' Lambda &, 968 &, 748 & 9,000 & 494,199 &, 664 & - \\
\hline${ }^{*} \leq 0.05$
\end{tabular}

Cinsiyet ve Üniversite faktörlerine göre boş zaman tutum ölçeği alt boyutları ve toplam skoru iki-yönlü ANOVA ile test edilmiş ve erkek katılımcıların değişkenlerinin ortalama puanları arasında istatistiksel olarak anlamlı farklar bulunmuştur. Farkın hangi üniversitelerden kaynaklandığına ise Tukey-testi ile bakılmış ve aşağıda tabloda verilmiştir.

Tablo 10. Tukey Testi Duyussal ve Bilişsel Alt Boyutlarının Çoklu Karşılaştırmaları

Tukey HSD

\begin{tabular}{|c|c|c|c|c|c|c|}
\hline Cinsiyet & $\begin{array}{l}\text { Bağımlı } \\
\text { Değişkenler }\end{array}$ & (I) Üniversite & (J) Üniversite & Ortaama fark (I-J) & Std. hata & $\mathrm{p}$ \\
\hline \multirow[t]{24}{*}{ Erkek } & Duyussal & 1.Selçuk & Necmettin & $-6,84(*)$ & 2,021 & ,005 \\
\hline & & & Aksaray & $-5,06$ & 2,756 &, 260 \\
\hline & & & Nevşehir & $-4,69$ & 1,98 & ,088 \\
\hline & & 2.Necmettin & Selçuk & $6,84(*)$ & 2,021 & ,005 \\
\hline & & & Aksaray & 1,78 & 3,05 & ,937 \\
\hline & & & Nevşehir & 2,15 & 2,38 & ,803 \\
\hline & & 3.Aksaray & Selçuk & 5,06 & 2,75 &, 260 \\
\hline & & & Necmettin & $-1,78$ & 3,05 & ,937 \\
\hline & & & Nevşehir & 0,36 & 3,03 & ,999 \\
\hline & & 4.Nevşehir & Selçuk & 4,69 & 1,98 & ,088 \\
\hline & & & Necmettin & $-2,15$ & 2,38 & ,803 \\
\hline & & & Aksaray & $-0,36$ & 3,03 & ,999 \\
\hline & Bilissel & 1.Selçuk & Necmettin & $-9,21\left(^{*}\right)$ & 1,98 & ,000 \\
\hline & & & Aksaray & $-4,36$ & 2,70 & ,373 \\
\hline & & & Nevşehir & $-6,02(*)$ & 1,94 & ,012 \\
\hline & & 2.Necmettin & Selçuk & $9,21(*)$ & 1,98 & 000 \\
\hline & & & Aksaray & 4,85 & 2,99 & ,368 \\
\hline & & & Nevşehir & 3,18 & 2,33 &, 522 \\
\hline & & 3.Aksaray & Selçuk & 4,36 & 2,70 & ,373 \\
\hline & & & Necmettin & $-4,85$ & 2,99 & ,368 \\
\hline & & & Nevşehir & $-1,66$ & 2,97 & ,944 \\
\hline & & 4.Nevşehir & Selçuk & $6,02(*)$ & 1,94 & ,012 \\
\hline & & & Necmettin & $-3,18$ & 2,33 &, 522 \\
\hline & & & Aksaray & 1,66 & 2,97 & ,944 \\
\hline
\end{tabular}

Boş zaman değerlendirme tutum ölçeğinin cinsiyet faktörü ve üniversite faktörüne bakıldığında erkek katılımcıların duyuşsal alt boyutunda Selçuk ve Necmettin Erbakan Üniversiteleri arasında ve bilişsel alt boyutunda ise yine Selçuk ve Necmettin Erbakan ile Nevşehir Üniversiteleri arasında istatistiksel olarak anlamlı farklar bulunmuştur ( $\mathrm{p} \leq 0.05)$. 
Tablo 11. Tukey Testi Davranışsal Alt Boyutu ve Toplam Anket Puanının Çoklu Karşılaştırmaları

Tukey HSD

\begin{tabular}{|c|c|c|c|c|c|c|}
\hline Cinsiyet & $\begin{array}{l}\text { Bağımlı } \\
\text { Değişkenler }\end{array}$ & (I) Üniversite & (J) Üniversite & $\begin{array}{l}\text { Ortaama } \\
\text { fark }(I-J)\end{array}$ & Std. hata & $\mathrm{p}$ \\
\hline \multirow[t]{24}{*}{ Erkek } & Davranıssal & 1.Selçuk & Necmettin & $-4,58$ & 1,87 &, 071 \\
\hline & & & Aksaray & $-2,92$ & 2,55 & ,662 \\
\hline & & & Nevşehir & $-1,57$ & 1,84 & ,827 \\
\hline & & 2.Necmettin & Selçuk & 4,58 & 1,87 &, 071 \\
\hline & & & Aksaray & 1,66 & 2,82 & ,936 \\
\hline & & & Nevşehir & 3,00 & 2,20 &, 524 \\
\hline & & 3.Aksaray & Selçuk & 2,92 & 2,55 & ,662 \\
\hline & & & Necmettin & $-1,66$ & 2,82 & ,936 \\
\hline & & & Nevşehir & 1,34 & 2,80 & ,963 \\
\hline & & 4.Nevşehir & Selçuk & 1,57 & 1,84 & 827 \\
\hline & & & Necmettin & $-3,00$ & 2,20 &, 524 \\
\hline & & & Aksaray & $-1,34$ & 2,80 & ,963 \\
\hline & Toplam Puan & 1.Selçuk & Necmettin & $-20,64(*)$ & 5,27 & ,001 \\
\hline & & & Aksaray & $-12,34$ & 7,19 &, 318 \\
\hline & & & Nevşehir & $-12,29$ & 5,19 & ,087 \\
\hline & & 2.Necmettin & Selçuk & $20,64(*)$ & 5,27 & ,001 \\
\hline & & & Aksaray & 8,29 & 7,97 & ,726 \\
\hline & & & Nevşehir & 8,34 & 6,22 &, 537 \\
\hline & & 3.Aksaray & Selçuk & 12,34 & 7,19 & ,318 \\
\hline & & & Necmettin & $-8,29$ & 7,97 &, 726 \\
\hline & & & Nevşehir & 0,05 & 7,91 & 1,000 \\
\hline & & 4.Nevşehir & Selçuk & 12,29 & 5,19 &, 087 \\
\hline & & & Necmettin & $-8,34$ & 6,22 &, 537 \\
\hline & & & Aksaray & $-0,05$ & 7,91 & 1,000 \\
\hline
\end{tabular}

Boş zaman Değerlendirme tutum ölçeği toplam puanında ise Selçuk ve Necmettin Erbakan Üniversiteleri erkek katılımcıların skorlarında istatistiksel olarak farka rastlanmıştır $(\mathrm{p} \leq 0.05)$.

Tablo 12. Bütün Katılımcıların Yaşadıkları Yere Göre Boş Zaman Tutum Ölçeği Alt Boyutları ve Toplam Puan Değerlerinin Ortalama (x) ve Standart Sapmaları (SS).

\begin{tabular}{lllll}
\hline & N & Ortalama $(\mathrm{X})$ & Standart Sapma (SS) \\
\hline Duyuşsal & Büyükşehir & 192 & 50,66 & 10,22 \\
& İlmerkezi & 74 & 50,05 & 9,82 \\
& İlçe & 92 & 49,36 & 9,35 \\
& Kasaba & 19 & 54,89 & 7,67 \\
& Köy & 41 & 49,21 & 13,78 \\
& Toplam & 419 & 50,30 & 10,28 \\
\hline Bilişsel & Büyükşehir & 192 & 47,68 & 10,27 \\
& İl merkezi & 74 & 47,89 & 9,77 \\
& İlçe & 92 & 46,19 & 9,21 \\
& Kasaba & 19 & 48,63 & 10,71
\end{tabular}




\begin{tabular}{lllll} 
& Köy & 41 & 44,00 & 12,33 \\
& Toplam & 419 & 47,07 & 10,22 \\
\hline Davranışsal & Büyükşehir & 192 & 43,35 & 10,04 \\
& İl merkezi & 74 & 43,62 & 8,92 \\
& İlçe & 92 & 42,37 & 7,47 \\
& Kasaba & 19 & 47,42 & 8,50 \\
& Köy & 41 & 43,29 & 10,71 \\
& Toplam & 419 & 43,36 & 9,34 \\
\hline Toplam & Büyükşehir & 192 & 141,70 & 27,44 \\
& İl merkezi & 74 & 141,56 & 25,54 \\
& İlçe & 92 & 137,76 & 22,68 \\
& Kasaba & 19 & 150,94 & 21,51 \\
& Köy & 41 & 136,51 & 34,86 \\
& Toplam & 419 & 140,71 & 26.7
\end{tabular}

Bütün katılımcıların yaşadıkları yere göre boş zaman tutum ölçeği alt boyutları ve toplam puan değerlerinin ortalama ve standart sapmaları incelendiğinde en yüksel ortalama değerlere kasabada yaşayanların sahip olduğu $(n=19, x=150,94)$ görülmüş, en düşük değerlere ise köyde yaşayan katılımcılarda $(n=41, x=136,51)$ rastlanmıştır.

Tablo 13. Bütün Katılımcıların Yaşadıkları Yere Göre Boş Zaman Tutum Ölçeği Alt Boyutları ve Toplam Puan Değerlerinin One-Way ANOVA(Tek-Yönlü ANOVA) ile Analizi

\begin{tabular}{lllllll}
\hline & ANOVA & $\begin{array}{l}\text { Kareler } \\
\text { Toplamı }\end{array}$ & df & Kare & & \\
& & Ortalaması & F & p \\
\hline Duyuşsal & Gruplararası & 586,564 & 5 & 117,31 & 1,109 & 0,35 \\
& Gurupiçi & 43566,62 & 414 & 105,74 & & \\
& Toplam & 44153,18 & 419 & & & \\
Bilişsel & Gruplararas1 & 630,568 & 5 & 126,11 & 1,210 & 0,30 \\
& Gurupiçi & 43035,28 & 414 & 104,20 & & \\
& Toplam & 43665,85 & 419 & & & \\
Davranışsal & Gruplararas1 & 412,703 & 5 & 82,54 &, 945 & 0,45 \\
& Gurupiçi & 35992,02 & 414 & 87,35 & & \\
& Toplam & 36404,72 & 419 & & & \\
& Gruplararası & 3833,489 & 5 & 766,69 & 1,071 & 0,37 \\
& Gurupiçi & 294253,12 & 414 & 715,94 & & \\
& Toplam & 298086,60 & 419 & & &
\end{tabular}

Bütün katılımcıların yaşadıkları yere göre boş zaman tutum ölçeği alt boyutları ve toplam puan değerlerinin tek yönlü varyans analizi ile değerlendirilmesi sonucunda hiçbir değişkende istatistiksel olarak anlamlı bir farka rastlanmamıştır ( $>0.05)$.

\section{TARTIŞMA}

Öğrencilerin anne öğrenim durumuna yönelik istatistik tablosu incelendiğinde boş zaman tutum ölçeği alt boyutlarından bilişsel ve duyuşsal boyutta anlamlı farklılık bulunmuş olup davranışsal boyutta anlamlı bir 
farklılığa rastlanmamıştır. Yapılan tukey testi sonuçları incelendiğinde duyuşsal boyutta ilkokul-orta okul ve lise mezunu anneler ile lisansüstü mezunu anneler arasında farklılık olduğu tespit edilmiştir. $\mathrm{Bu}$ farklılık ilkokul-ortaokul ve lise mezunu anneler lehine olduğu görülmektedir. Lisansüstü ve yüksek okul mezunu anne eğitiminin öğrencilerin boş zaman tutumunda bir etkiye sahip olmadığ görülmüştür. Yani anne eğitiminin artması öğrencilerin boş zaman tutumlarını da aynı ölçüde artırmamıştır. (Akyüz, 2015: 62 ve Arguz, 2018: 50) Anne eğitim durumuna göre boş zaman tutum ölçeği alt boyutlarında anlamlı bir farklılığın olmadığını tespit etmişlerdir. Çalışmamız bu çalışmalarla farklılık göstermektedir. Bu farklılığın örneklem grubundan kaynaklanmış olabileceği düşünülmektedir.

Öğrencilerin baba öğrenim durumuna yönelik istatistik tablosu incelendiğinde boş zaman tutum ölçeği alt boyutlarında anlamlı bir fark bulunmadı. (Akyüz, 2015: 65 ve Arguz, 2018: 52) Baba eğitim durumuna göre boş zaman tutum ölçeği alt boyutlarında anlamlı bir farklılık bulunmamıştır. Çalışmamızın sonuçları (Akyüz ve Arguz 'un) bulmuş oldukları sonuçlarla benzerdir. Bu sonuçlara göre baba eğitiminin üniversite öğrencilerinin boş zaman tutumunda bir etkiye sahip olmadığı görülmüştür.

Gelir değişkenine göre boş zaman tutum ölçeği alt boyutlarında anlamlı bir fark bulunmamıştır ( $>0005)$. (Arguz, 2018: 53) Üniversite öğrencileri üzerine yapmış olduğu çalışmasında boş zaman tutum ölçeği alt boyutlarında anlamlı bir farklılığa rastlamamıştır. Bu sonuçlar çalışmamızda elde ettiğimiz sonuçlarla örtüşmektedir. $\mathrm{Bu}$ sonuçlara göre gelirin üniversite öğrencilerinin boş zaman tutumunda bir etkiye sahip olmadığ1 görülmüştür.

Kaldığı yer anova sonuçları incelendiğinde duyuşsal alanda anlamlı bir farklılığa rastlanmıştır. Bu farklıı̆̆ın hangi gruplardan kaynaklandığına Tukey testiyle bakılmış ve gruplar arasında anlamlı bir farklılığa rastlanmamıştır. Bu sonuca göre öğrencilerin kaldığı yerin boş zaman tutumlarını etkilemediği söylenebilir (Akyüz, 2015: 73) çalışmasında öğrencilerin öğrenim gördükleri ilde kaldıkları yer değişkenin boş zaman tutumunu etkilemediği sonucunu bulmuştur. Araştırmamızda elde ettiğimiz sonuçlar bu çalışmayla benzerdir.

Cinsiyet değişkenine göre boş zaman tutum ölçeği alt boyutları incelendiğinde duyuşsal, bilişsel ve davranışsal bileşenlerde kız öğrencilerin boş zaman tutumlarının erkek öğrencilere göre daha yüksek olduğu görülmüştür. Cinsiyete göre boş zaman tutum ölçeği alt boyutları olan duyuşsal ve bilişsel bileşenlerde, davranışsal bileşenlere göre daha yüksek değerler görülmüştür. Katılımcıların boş zaman tutumuyla ilgili olarak bilgi ve duyuşları davranışların ortaya çıkmasında önemli bir faktör olduğu söylenebilir. Aşağıda yapılan çalışmalarla benzer sonuçlara ulaşıldığı görülmüştür:

(Akyüz, 2015:54) Çalışmasında, cinsiyet değişkeni ile ilgili erkek ve kadın öğrenciler arasında duyuşsal alan, bilişsel alanda ve toplamda anlamlı farklılığın olduğunu belirtmiştir. Davranışsal alanda ise anlamlı farklılık gözlenmemiştir. Kadın üniversite öğrencilerinin boş zaman tutum puanları bütün alt boyutlarda erkeklerden yüksek çıkmıştır. (Kaya, 2015:53) Cinsiyet ve yaş değişkeninin bireylerin tutumlarını etkilediğini belirtmiştir. Kadınların boş zaman tutumlarının erkeklere göre daha yüksek olduğunu tespit etmiştir. Bulgularımızla farklılık gösteren çalışmalara bakıldığında;

(Akgül ve Yenel, 2014: 138) Çalışmalarında cinsiyete göre boş zaman tutum ölçeği alt boyutlarına bakıldığında Ankara'daki bireylerin bilişsel alt boyutta farklılık bulunurken duyuşsal ve davranışsal bileşenlerde anlamlı farklılık görülmemiştir. Ayrıca Ankara'da erkeklerin boş zaman tutumlarının kadınlara göre daha olumlu olduğu tespit edilmiştir. Londra'daki bireylerde ise üç alt boyutta da bir farklılık olmadığını ifade etmişlerdir. Bu sonuçlar çalışmamızla farklılık göstermektedir.

Literatürde cinsiyet ile boş zaman tutumu arasında farklı sonuçlar bulunduğu görülmektedir. (Muzindutsi ve Viljoen, 2016:111) Erkek ve kız öğrenciler arasında boş zaman tutumunda bir fark olmadığını cinsiyetin boş zaman tutumunda bir etkiye sahip olmadığını tespit etmiştir. (L. Neşe Aslan, 2000:179) Öğrencilerin \%90 oranında katılmak istedikleri boş zaman aktivitelerine cinsiyetlerinin engel oluşturmadığını ifade etmiştir. (Gökyürek, 2016:3290-91) Yaptığı çalışmada Boş Zaman Tutum Ölçeğinin ortalama puanları, katılımcıların bilişsel alt ölçeğinde en yüksek puan ortalamasına sahip olduklarını göstermektedir. Araştırmanın bir başka bulgusu da, dans etkinliklerine katılan bireylerin boş zaman tutumu, cinsiyet, yaş ve eğitim düzeyine göre farklılık göstermemiştir. (Munusturlar, 2017:52-54) Boş zaman tutum ölçeği alt boyutlarından bilişsel tutumun en yüksek skora sahip olduğu görülmektedir. Türkiye'nin doğu ve batı illerinde yaşayan bireylerin boş zaman tutumunun cinsiyet bağımsız değişkeninden etkilenmediğini tespit etmiştir. Bu çalışmayla farklı bir sonuç ortaya çıkmıştır. Burada toplumsal ve kültürel farklılıkların cinsiyetin boş zaman tutumu üzerinde farklı sonuçlar ortaya çıkardığı görülmektedir. Bulgularımızla bu çalışmaların sonuçları örtüşmemektedir.

Cinsiyetin boş zaman tutumunda farklı sonuçların çıkması bölgeler ve kültürler arası farklılıklar ile örneklem grubu farklılıklarından kaynaklandığı söylenebilir.

Yine boş zaman tutum ölçeğinin cinsiyet ve üniversite faktörüne bakıldığında erkek katılımcılarda farklılık olduğu bulunmuştur. Bu farklılığın duyuşsal alanda Selçuk ve Necmettin Erbakan Üniversitesi arasında, 
bilişsel alanda ise Selçuk, Necmettin Erbakan ile Nevşehir Hacı Bektaş Veli Üniversitesi arasında anlamlı olduğu görülmektedir. Toplamda ise Selçuk ve Necmettin Erbakan Üniversiteleri arasında anlamlı farklılık bulunmuştur. Bu farklılığın Necmettin Erbakan Üniversitesi erkek öğrencileri lehine olduğu tespit edilmiştir. Necmettin Erbakan Üniversitesi erkek öğrencilerinin boş zaman tutumunda bilgi düzeyi ve olumlu duyguları diğer katılımcılara göre daha yüksek olduğu söylenebilir. Her iki üniversitenin de büyük şehirde olması erkek öğrencilerin boş zaman tutumlarında bilme ve duygu boyutunda olumlu katkı sağladığı düşünülebilir. Ayrıca Aksaray Üniversitesi’nde anlamlı farklılığın görülmemesi Turizm Fakültesi’nin öğrenci sayısının diğer üniversitelere göre daha az olmasından kaynaklandığı düşünülmektedir.

Öğrencilerin yaşam yerlerinin boş zaman tutumlarını etkilemediği tespit edilmiştir. (Munusturlar, 2017:5354) Bireylerin ikamet ettikleri yerin ve ikamet bölgesinin boş zaman tutumunu etkilediğini tespit etmiştir. Bu çalışmadaki farklı sonuçlar bölgeler arasındaki farklılıktan kaynaklanıyor olabilir.

\section{SONUÇ}

Sonuç olarak KOP bölgesi üniversiteleri Turizm Fakültesi son sınıf ögrencileri rekreasyon faaliyetlerine katılımın başarılarını artırdığını, rekreasyonel etkinliklere katılım için yeterli boş zamana sahip olduklarını fakat bu boş zamanlarını yeterli düzeyde olumlu kullanamadıklarını, üniversitenin sunduğu boş zaman olanaklarını yetersiz bulduklarını ifade etmişlerdir. Öğrencilere sunulan boş zaman etkinliklerinin yetersizliği öğrencilerin boş zamanlarını verimli bir şekilde geçirmelerine engel teşkil edebilir. Yine öğrenciler boş zamanlarını en çok arkadaşlarıyla değerlendirdiklerini ifade etmişlerdir. Bu nedenle üniversiteler öğrencilere yeterli düzeyde ve farklı boş zaman etkinlikleri planlarken arkadaş grubuyla katılım sağlanacak etkinlikleri göz önünde bulundurmaları bu etkinliklere olan katılım oranını artırabilir. KOP bölgesi üniversiteleri turizm fakültesi öğrencilerin boş zaman tutumlarında demografik özelliklerden gelir, aile yaşam yeri, kalınan yer ve baba eğitimine göre bir değişiklik olmazken anne eğitiminin bilişsel ve duyuşsal alanda önemli farklılık oluşturduğu bulunmuştur. Yine cinsiyetin öğrencilerin boş zaman tutumunu etkilediği kız öğrencilerin erkek öğrencilere göre daha olumlu bir tutuma sahip oldukları görülmüştür.

\section{ÖNERILER}

Boş zaman faaliyetleri planlanırken öğrencilerin istek ve beklentileri dikkate alınmalı, katılımcıların olumlu kişisel imaj geliştirebilmelerini ve güçlü sosyal ilişkiler kurmalarını sağlamalıdır. Aktivitelere katılımı teşvik ederek akademik programlar dışında üniversite deneyimlerini zenginleştirmek ve liderlik yetenekleri kazandırma, kendini birçok yönden geliştirme, kendini bulma ve keşfetme gibi amaçları gerçekleştirebilecek düzeyde planlı etkinliklere yer verilebilir. Planlı etkinlikler öğrencilerin yetenek ve kişilik gelişimine de önemli katkı sunarken onların boş zamanlarında kötü alışkanlıklardan korunmasına yardımcı olabilir. Rekreasyon etkinliklerinin planlanması ve uygulanması aşamaları uzmanlık gerektiren konular olduğundan KOP bölgesi üniversitelerinin ilgili alanda uzman kişilere yer vermesi bölge üniversiteleri arasındaki etkileşimin artmasına, üniversiteler arasındaki farkların azalmasına ve bölgenin bilinirliği ve turizmi açısından önemli katkıları olabilir. Üniversiteler yerel yönetimlerle birlikte hareket ederek öğrencilerin boş zaman imkânlarını keşfetmelerine çözüm üretebilir. Boş zaman etkinliklerine aktif katılımı artırmak için yerel yönetimlerle birlikte boş zaman danışmanlığı hizmeti sağlanabilir. Boş zaman katılımının önemi ve faydaları hakkında bilinirlik düzeylerini artırmak için sosyal medya gibi iletişim yollarında yararlanılabilir.

Üniversite öğrencilerinin, akademik ve idari, ekonomik, kişisel, yaşamsal, sağllk, sosyal ve kültürel, bağımlılık ve psikolojik, aidiyet, inanç ve ahlaki sorunlarını, gelecekle ilgili hayallerini ve öz eleştirilerini sunabilecekleri çalıştayların veya toplantıların yapılması; öğrencilerin boş zamanlarındaki yapabilecekleri faaliyetlerdeki beklentilerinin karşılanmasında önemli bir rolü olacağı düşünülebilir.

Bu başlıklar altında farklı anket formları düzenlenebilir. 


\section{KAYNAKÇA}

Akgül, Beyza Merve, ve Bülent Gürbüz, (2011) "Boş Zaman Tutum Ölçeği: Geçerlik Ve Güvenirlik Çalışması." Gazi Beden Eğitimi Ve Spor Bilimleri Dergisi 16.1, s 37-43.

Akgül, Beyza Merve ve İ. Fatih Yenel, (2014) Evaluation of Attitudes of İndividuals Towards Leisure Time Activities in Different Cultures: Ankara-London Case,Vol.,4(2), İnternational Journal of Sport Studies.

Akyüz, Hayri, (2015) "Beden Eğitimi ve Spor Yüksekokulu Bölümünde Öğrenim Gören Üniversite Öğrencilerinin Boş Zaman Faaliyetlerini Değerlendirilme Biçimlerinin İncelenmesi," International Journal of Science Culture and Sport (IntJSCS), s 3.

Ardahan, Faik ve Tennur Yerlisu Lapa, (2010) Üniversite Öğrencilerinin Serbest Zaman Tatmin Düzeylerinin Cinsiyete ve Gelire Göre İncelenmesi, Spor Bilimleri Dergisi Hacettepe J. of Sport Sciences, Ankara.

Arguz, İrfan, (2018) "Üniversite Öğrencilerinin Rekreatif Faaliyetlere Yönelik Tutumları ve Boş Zaman Motivasyonlarının İncelenmesi’, yayınlanmamış yüksek lisans tezi. Necmettin Erbakan Üniversitesi Sosyal Bilimler Enstitüsü, Konya.

Aslan, L. Neşe, (2000) Üniversite Öğrencilerinin Boş Zaman Değerlendirme Eğilimi, 3, Ege Üniversitesi Eğitim Fakültesi Yayınları, İzmir.

Binbaşıŏlu, Hulisi ve Hakan Tuna, (2014) Üniversite Öğrencilerinin Boş Zamanlarına Yönelik Tutumları: Doğu Anadolu Bölgesindeki MYO Öğrencilerine Yönelik Bir Araştırma, 2, Akademik Yaklaşımlar Dergisi, journal of academic approaches.

Bulut, Murat ve Funda Koçak, (2016) Hazırlık Öğrenimi Gören Kadın Üniversite Öğrencilerinin Rekreatif Etkinliklere Katılmalarını Engelleyen Faktörlerin Belirlenmesi, 2, Spor ve Performans Araştırmaları Dergisi Journal of Sports and Performance Researches, Samsun.

Caldwell, Linda L, (2005) 'Leisure and health: why is leisure therapeutic'? British Journal of Guidance\&Counselling, $33: 1$, s 7-26.

Çoruh, Yaşar ve Suat Karaküçük, (2014) Üniversite Öğrencilerinin Cinsiyet Değişkenine Göre Rekreasyonel Eğilimleri ve Rekreasyonel Etkinliklere Katılımına Engel Olan Faktörler,1, International Journal of Science Culture and Sport.

Ekinci, Nurullah Emir ve diğ., (2014) Üniversite Öğrencilerinin Sportif ve Sportif Olmayan Rekreatif Etkinliklere Katılmalarına Engel Olabilecek Unsurların İncelenmesi,1, Sportif Bakış: Spor ve Eğitim Bilimleri Dergisi.

Gökyürek, Belgin, (2016) 'An Analysis of Leisure Attitudes of the Individuals Participating in Dance Activities and the Relationship between Leisure Attitude and Life Satisfaction',10, İnternational Journal of Environmental.

Gül, Atila ve diğ., (2016) Süleyman Demirel Üniversitesi Öğretim Elemanları ve Öğrencilerinin Yerleşke İçindeki Rekreasyonel Talep ve Eğilimleri,1, Süleyman Demirel Üniversitesi Mimarlık Bilimleri ve Uygulamaları Dergisi, Isparta.

Hacıŏglu, Necdet ve diğ., (2009) Boş Zaman ve Rekreasyon Yönetimi,2, Detay Yayıncıllk, Ankara.

Hudson, Simon, (2000) "The Segmentation Of Potential Tourists: Constraint Differences Between Man and Women", Journal of Travel Research, 38, s 363-368.

Jong-Ho, Kim ve Mc Kenzie Lary A, (2014) The İmpacts of Physical Exercise on Stress Coping and Well-Being in Universty Students in the context of Leisure,6, Health.

Kaya, Sabri ve Bülent Gürbüz, (2015) An Examination of University Students Attitudes Towards Leisure Activities, 3/6, Pamukkale Journal of Sport Sciences.

Karaçar, Ercan ve Mehmet Mert Paslı, (2014) Turizm ve Otel İşletmeciliği Programı Öğrencilerinin Rekreasyonel Eğilimleri ve Rekreasyonel Etkinliklere Katılımına Engel Olan Faktörler, 1,Turizm Akademik Dergisi.

Karaküçük, Suat, (2005) Rekreasyon: Boş Zamanları Değerlendirme, 4. baskı, Gazi Kitapevi, Ankara.

Karaküçük, Suat, (2016) Rekreasyon Bilimi, Gazi Kitapevi, Ankara.

Kılbaş, Şükran, (2010) Rekreasyon Boş Zamanları Değerlendirme, 4. Baskı, Gazi Kitabevi, Ankara.

Kılıç, Metin ve Gülden Şener, (2013) Üniversite Öğrencilerinin Rekreasyon Etkinliklerine Katılımlarındaki Sosyolojik Etkenler ve Yapısal Kısıtlamalar, 3,Yükseköğretim ve Bilim Dergisi/Journal of Higher Education and Science.

Lim Khong, Chiu, (2009) 'University Students Attitude, Self- Efficacy and Motivation Regarding Leisure Time Physical participation',Jurnal Pendidikdan Pendidikan, 24, s 1-15.

Lim Khong, Chiu ve Kalsom Kayat, (2010) Psychological Determinants of Leisure Time Physical Activity Participation among Public University Students in Malaysia,2, Ajtlhe Vol.2.

Luo, Lu ve Shu-Fang Kao, (2009) Leisure Participation and Leisure Satisfaction: Moderating Effects of Personality Traits,3, Vol:3, Journal of Sport and Recreation Research.

Luo, Lu ve Hu, Chia-hsın, (2005) Personality, Leisure Experiences and Happiness,6, Journal of Happiness Studies.

Munusturlar, Süleyman, (2017) 'Examination of the Leisure Attitudes of İndividuals Living in Turkey From An East to West Perspective', 2/105, Baltıc Journal of Sport Health Sciences.

Muzindutsi, Paul-Francois, ve Diana Viljoen, (2016) Socio-Demographic Factors Influencing Leisure Attitude Among Undergraduate Students at a South African Universty, 1, İnternational Journal of Social Sciences and Humanity Studies. 
Richard L. Gage ve Brijesh Thapa, (2012) Volunteer Motivations and Constraints Among College Students: Analysis of the Volunteer Function Inventory and Leisure Constraints Models,41(3), Nonprofit and Voluntary Sector Quarterly.

Sağcan, Mustafa, (1986) Rekreasyon ve Turizm, Cumhuriyet Basımevi, İzmir.

Sanghee, Chun ve diğ., (2012) The Contribution of Leisure Participation and Leisure Satisfaction to Stress-Related Growth,34:5, Leisure Sciences.

Sevil, Tuba ve diğ., (2012) Boş Zaman ve Rekreasyon Yönetimi, 1, Anadolu Üniversitesi Yayınları, Eskişehir.

Somuncu, Mehmet ve diğ., (2015) Ankara'daki Üniversite Öğrencilerinin Rekreasyonel Eğilimlerinin Saptanması, 3, III. Rekreasyon Araştırmaları Kongresi, Eskişehir.

Sunyoong, Kim ve diğ., (2015) The Relationship among Leisure Attitude, Satisfaction, and Psychological Wellbeing for College Students, 15(1), Journal of Physical Education and Sport (JPES), s 70-76.

Tercan Kaas, Evren, (2015) "Üniversite Öğrencilerinde Rekreasyon Aktivitelerine Katılım, Yaşam Tatmini, Algılanan Stres ve Benlik Saygısının İncelenmesi” III. Rekreasyon Araştırmaları Kongresi, s. 568-576.

Torkildsen, George, (2005) Recreation and Leisure Management. 5th edition. Taylor and Francis Group, Londonand New York.

Tütüncü, Özkan ve diğ., (2011) Üniversite Öğrencilerinin Rekreasyon Faaliyetlerine Katılımını Etkileyen Unsurların Analizi, 22, Spor Bilimleri Dergisi Hacettepe J. of Sport Sciences.

Yerlisu Lapa, Tennur ve Evren Ağyar, (2012) Üniversite Öğrencilerinin Serbest Zaman Katılımlarına göre Algılanan Özgürlük, 23, Spor Bilimleri Dergisi Hacettepe J. of SportSciences.

Xinran, Y. Lehto ve diğ., (2014) Student Life Stress and Leisure Participation, 17:2, Annals of Leisure Research. 